\title{
Adsorption of reactive dyes from aqueous solutions by tannery sludge developed activated carbon: Kinetic and equilibrium studies
}

\author{
*A. Geethakarthi; B. R. Phanikumar \\ Department of Mechanical and Building Sciences, VIT University, Vellore, India
}

Received 6 September 2010; $\quad$ revised 6 November 2010; accepted 9 March 2011; $\quad$ available online 1 June 2011

\begin{abstract}
Adsorption kinetic and equilibrium studies of two reactive dyes, namely, Reactive Red 31 and Reactive Red 2 were conducted. The equilibrium studies were conducted for various operational parameters such as initial dye concentration, $\mathrm{pH}$, agitation speed, adsorbent dosage and temperature. The initial dye concentration was varied from $10-60 \mathrm{mg} / \mathrm{L}, \mathrm{pH}$ from $2-11$, agitation speed from 100-140 rpm, adsorbent dosage from $0.5 \mathrm{~g}$ to $2.5 \mathrm{~g}$ and temperature from $30{ }^{\circ} \mathrm{C}-50{ }^{\circ} \mathrm{C}$ respectively. The activated carbon of particle size $600 \mu \mathrm{m}$ was developed from preliminary tannery sludge. The dye removal capacity of the two reactive red dyes decreased with increasing $\mathrm{pH}$. The zero point charge for the sludge carbon was 9.0 and 7.0 for the two dyes, respectively. Batch kinetic data investigations on the removal of reactive dyes using tannery sludge activated carbon have been well described by the lagergren plots. It was suggested that the Pseudo second order adsorption mechanism was predominant for the sorption of the reactive dyes onto the tannery sludge based carbon. Thus, the adsorption phenomenon was suggested as a chemical process. The adsorption data fitted well with Langmuir model than the Freundlich model. The maximum adsorption capacity $\left(\mathrm{q}_{0}\right)$ from Langmuir isotherm were found to have increased in the range of $23.15-39.37 \mathrm{mg} / \mathrm{g}$ and $47.62-55.87 \mathrm{mg} / \mathrm{g}$ for reactive dyes reactive red 31 and reactive red 2, respectively.
\end{abstract}

Keywords: Adsorbent; Lagergren plot; Langmuir isotherm; Surface area; Zero point charge

\section{INTRODUCTION}

Dyes are natural or synthetic colorants used in various industries such as textiles, tanneries, paints, pulp and paper. Even if a small amount of dye is present in water, it is visible and therefore undesirable (Robinson et al., 2001). Over 1,00,000 commercially available dyes exist and more than $7 \times 10^{5}$ ton of dyes are produced annually. During the dyeing process, $10-15 \%$ of the dye is lost in the effluent (Garg et al., 2003) and hence effluents discharged from dyeing industries are highly colored and are toxic to aquatic life in the receiving water bodies. Some dyes are carcinogenic which require separation and advanced treatment before they are discharged into conventional systems. However, wastewater containing dyes is difficult to treat, since the dyes are recalcitrant organic molecules, resistant to aerobic digestion and are stable to light, heat and oxidizing agents (Sun and Yang, 2003). The removal of color from dye-house liquid effluents is one of the major

\footnotetext{
ه *Corresponding Author Email: geethakarthi@yahoo.com
} Tel.: +91 94434 52576; Fax: +2243092 2240411 problems of the textile industry. Azo dyes which are used extensively in many industries are the largest class of synthetic dyes with a wide variety of color and structure (Samarghandi et al., 2007; Gharbani et al., 2008). One problematic group is the reactive dye - the largest single group of dyes used in the textile industry. Being highly water soluble and practically nonbiodegradable, reactive dyes are not degraded in municipal activated sludge treatment plants nor are they substantially removed via adsorption onto the biomass. Various types of reactive dyes are commercially available. Reactive dyes typically have a relatively low fixation degree on the textile substrate and the corresponding wastewaters may be highly colored. Despite the existence of a wide range of wastewater treatment techniques, there is no single process capable of adequate mineralization of colored effluents, mainly due to their complex nature (Naim and Abd, 2002; Atafar et al., 2010). A final refining treatment is required which usually involves oxidation with ozone (Hsu et al., 2001), Fenton's reactant (Ferrero, 2000) or 
hydrogen peroxide + UV radiation (Uygur and Kok, 1999; Fung et al., 2000), membrane separation (Ciardelli et al., 2000) or adsorption, usually on activated carbon (Walker and Weatherley, 1999). Reliable results have been obtained by the combination of some of these methods for the treatment of wastewaters containing dyes and other organic contaminants (Chien and Shih, 2007; Hassani et al., 2008). Among the physicochemical processes, adsorption technology is considered to be most effective and proven technology having wide potential for applications in both water and wastewater treatment. Adsorption process is used in a variety of important industrial applications and now it is increasingly used on large scale as an economical and efficient separation technique for metal ion removal from wastewater (Zvinowanda et al., 2009).

An alternative treatment for the discoloration of wastewaters from the textile industry is the usage of some non-conventional adsorbents (natural materials, biosorbents and waste materials from industry and agriculture) with lower cost and high efficiency (Shukla et al., 2002; Forgacs et al., 2004; Crini, 2006). Industrial wastes represent unused resources and cause serious disposal problems. These waste materials are to be turned into a useful resource for the color removal of various dyes. The tannery industry is also inserted into this context. Previous investigations showed that sludge based activated carbons obtained in the presence of sulphuric acid possessed relatively high adsorption capacity for aqueous dyes of large molecular weight (Maria Martin et al., 2003). The sludge based activated carbon and the commercial activated carbon by Maria Martin et al. (2003) was tested for their dye removal efficiency of three different cationic dyes and one anionic dye. The adsorptive capacity of sludge based activated carbon for anionic dyes decreased due to the negatively charged activated carbon surface. Several workers have also investigated the suitability of waste metal hydroxide sludge from electroplating industry for the removal of reactive dyes (Netpradit et al. 2003). Adsorption capacity of the metal hydroxide sludge varied from 44 to $60 \mathrm{mg} / \mathrm{g}$ for different reactive dyes (Netpradit et al. 2003). In this work, preliminary tannery sludge obtained from a common effluent treatment plant was pyrolysed into an activated carbon by acid activation. The activated sludge carbon of particle size $600 \mu \mathrm{m}$ was used in the removal of aqueous reactive dye solutions. The raw tannery sludge was collected from a tannery sector, Ranipet and the research was carried out in laboratory scale in VIT University, Vellore in India from 2009 to 2010.

\section{MATERIALS AND METHODS}

\section{Materials}

The preliminary tannery sludge was obtained from Ranitec, a common tannery effluent treatment plant, Ranipet, India comprising effluents from 76 tanneries. The collected sludge was dried and crushed. The dried sludge was pyrolyzed in a horizontal tubular furnace for activation. The pyrolyzed sludge carbon (SC600) was sieved to a particle size of $600 \mu \mathrm{m}$ and considered throughout the work. The surface area of the tannery sludge developed activated carbon was measured by Brunauer-Emmett-Teller nitrogen adsorption technique (BET). Table 1 shows the surface area, proximate and ultimate analysis of the raw tannery sludge and the sludge developed activated carbon. Reactive dyes of diazo compound (Reactive Red 31) and monoazo compound (Reactive Red 2) used in this the study was procured from Sigma - Aldrich chemicals (India). Reagent of analytical grade were used for analysis of samples.. Deinoized water was used in preparing solutions throughout the investigations. The physical properties of the two dyes are shown in Table 2.

Table 1: Properties of raw tannery sludge and tannery sludge activated carbon (SC600)

\begin{tabular}{lrr}
\hline Properties & Raw tannery sludge & Tannery sludge activated carbon \\
\hline BET surface area $\left(\mathrm{m}^{2} / \mathrm{g}\right)$ & 20.08 & 167.40 \\
$\mathrm{pH}$ & $7.2 \pm 0.01$ & $6.95 \pm 0.03$ \\
Moisture content (\%) & $3.6 \pm 0.02$ & $1.5 \pm 0.0$ \\
Volatile content (\%) & $32.5 \pm 0.03$ & $23.85 \pm 0.03$ \\
Ash content (\%) & $28.36 \pm 0.02$ & $18.75 \pm 0.02$ \\
Fixed carbon content (\%) & $35.54 \pm 0.03$ & $55.9 \pm 0.05$ \\
$\mathrm{C}$ & 34 & 54 \\
$\mathrm{H}$ & 1.8 & 2.0 \\
$\mathrm{~N}$ & 64.2 & 44 \\
\hline
\end{tabular}




\section{Methods}

The study of adsorption kinetics and equilibrium is essential in supplying the fundamental information required for the design and operation of adsorption equipments for wastewater treatment. The adsorption equilibrium studies of the sludge carbon (SC600) were conducted for various operational parameters such as initial dye concentrations, $\mathrm{pH}$, adsorbent dosage, agitation speed and temperature. The effect of varying initial dye concentration $(10 \mathrm{mg} / \mathrm{L}, 20 \mathrm{mg} / \mathrm{L}, 30 \mathrm{mg} / \mathrm{L}$, $40 \mathrm{mg} / \mathrm{L}, 50 \mathrm{mg} / \mathrm{L}$ and $60 \mathrm{mg} / \mathrm{L}), \mathrm{pH}(2.0,4.0,7.0,9.0$ and $11.0)$, adsorbent dosage $(0.5 \mathrm{~g}, 1.0 \mathrm{~g}, 1.5 \mathrm{~g}, 2.0 \mathrm{~g}$ and $2.5 \mathrm{~g})$, agitation speed (100 rpm, $120 \mathrm{rpm}$ and $140 \mathrm{rpm}$ ) and temperature $\left(30{ }^{\circ} \mathrm{C}, 40{ }^{\circ} \mathrm{C}\right.$ and $\left.50{ }^{\circ} \mathrm{C}\right)$ were studied. The experiments were carried out in batch mode of adsorption. The batch experiments were run by varying one of the operational parameters maintaining other parameters a constant. Thus, a $\mathrm{pH}$ of 7.0, an initial dye concentration $40 \mathrm{mg} / \mathrm{L}$, an adsorbent dosage $1.0 \mathrm{~g}$, an agitation speed $120 \mathrm{rpm}$ and a temperature of $30{ }^{\circ} \mathrm{C}$ were the arbitrarily chosen constants for the different series of experiments. For each experimental series, 100 $\mathrm{mL}$ of dye solution of known concentration, $\mathrm{pH}$, adsorbent dosage, agitation speed and temperature were used. The dye solutions were taken in a $250 \mathrm{~mL}$ Erlenmeyer flask for conducting the tests. The mixture was agitated in an orbital shaker at a constant speed of $120 \mathrm{rpm}$ for $24 \mathrm{~h}$ at a constant temperature of $30^{\circ} \mathrm{C}$. At predefined time intervals the solutions of the specified flask were separated from the adsorbent materials and concentration of dyes was determined spectrophotometrically on a cyberlab UV - visible spectrophotometer by measuring absorbance at a wavelength of 500, $538 \mathrm{~nm}$ for Reactive red 31 (RR 31 ) and Reactive red 2 ( $R R$ 2) reactive dyes respectively.

The $\mathrm{pH}$ of the dye solution was adjusted by $0.1 \mathrm{~N}$ $\mathrm{NaOH}$ or $0.1 \mathrm{~N} \mathrm{HCl}$. Kinetics of adsorption was determined by analyzing adsorptive uptake of the dye from aqueous solution at different time intervals. For adsorption isotherms, dye solutions of different concentrations were agitated with known amount of adsorbent at fixed $\mathrm{pH}$, agitation speed and particle size till the equilibrium time $(4 \mathrm{~h})$ was reached. The concentration retained in the adsorbent phase $\left(q_{e}\right.$, $\mathrm{mg} / \mathrm{g}$ ) was calculated by using the following equation:

$q_{e}=\frac{\left(C_{0}-C_{e}\right)}{W / V}$

Where, $\mathrm{C}_{\mathrm{o}}$ - initial dye concentration $(\mathrm{mg} / \mathrm{L}), \mathrm{C}_{\mathrm{e}}-$ equilibrium concentration of the dye $(\mathrm{mg} / \mathrm{L}), \mathrm{W}$ Adsorbent weight (g), V-Volume of the adsorbate solution (L), $\mathrm{q}_{\mathrm{e}}$-monolayer adsorption capacity of the adsorbent at equilibrium time $(\mathrm{mg} / \mathrm{g})$. All the experiments in this work were carried out in duplicate and the average results are presented.

\section{RESULTS AND DISCUSSION}

Effect of contact time and initial dye concentration on adsorption kinetics

The influence of initial dye concentration on adsorption of RR 31 and RR 2 onto SC600 was

Table 2: Properties of the reactive dyes

\begin{tabular}{lll}
\hline Name of the dye & & Reactive Red 31 \\
\hline Chemical class & diazo compound & Monoazo compound \\
Reactive system & Mono chlorotriazine & Di chlorotriazine \\
Other names & Reactive Brill. Red H8B & Reactive Brill. Red M5B
\end{tabular}

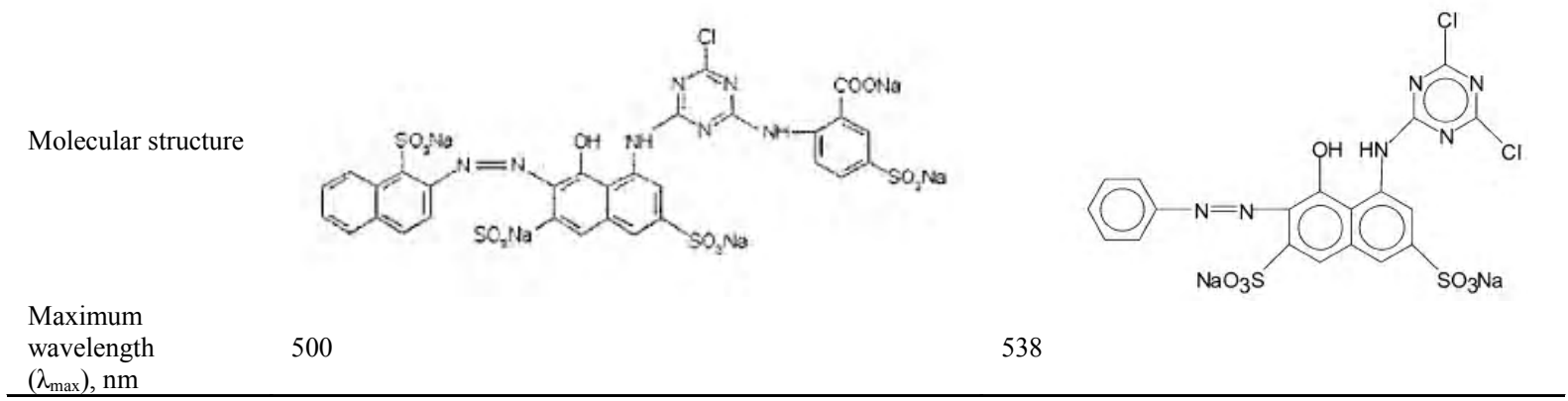


investigated in the concentration range $10-60 \mathrm{mg} / \mathrm{L}$ at $\mathrm{pH}-7.0,30^{\circ} \mathrm{C}$ and $1 \mathrm{~g} / 100 \mathrm{~mL}$ adsorbent dosage. When the initial dye concentration increased from $10-60 \mathrm{mg} / \mathrm{L}$, the amount of dye adsorbed increased from 8.511-34.266 $\mathrm{mg} / \mathrm{g}$ (SC600 RR31) and 9.477-43.198mg/g (SC600 RR2). The adsorption of the reactive dyes increased with time and then attained equilibrium at $4 \mathrm{hrs}$. For the initial concentration of dyes RR 31 and RR 2 of $40 \mathrm{mg} / \mathrm{L}$, the percent removal of dyes was $65.041 \%$ and $78.528 \%$. The dye removal percentage was higher for RR 2 than RR 31. Table 1 shows the effect of initial dye concentrations and their adsorption capacity. The percent removal of dyes decreased with increase in initial concentration and takes longer time to reach equilibrium because of the fact that, with increase in dye concentration, there will be increased competition for the active adsorption sites, strong chemical binding of the adsorbate and the adsorption process will increasingly slow down. A similar trend was reported for the adsorption of the dyes such as Reactive Red 241 onto a commercial activated carbon (Orfaco et al., 2006).

\section{Effect of adsorbent dosage on adsorption kinetics}

The adsorbent dosage of the various adsorbents varied from $0.5 \mathrm{~g} / 100 \mathrm{~mL}$ to $2.5 \mathrm{~g} / 100 \mathrm{~mL}$. For the initial concentration of $40 \mathrm{mg} / \mathrm{L}$, the dye adsorbed increased from 19.71-38.09 mg/g(RR31 SC600), 21.29-38.92 mg/g (RR2 SC600) for various adsorbent dosage and shown in Fig. 2. Initially, a rapid increase in adsorption with the increase in adsorbent dose was found, which can be attributed to greater surface area and availability of more adsorption sites. After the critical dose of $(1.5 \mathrm{~g} / 100 \mathrm{~mL})$ the extent of adsorption decreased. This phenomenon was also confirmed by Nandi et al. (2009). The increase in the colour removal is because, at higher carbon dosage, there is a very fast superficial adsorption on the carbon surface that produces a lower solute concentration in the solution than when carbon dose is lower.

\section{Effect of agitation speed on adsorption kinetics}

Agitation is an important parameter in adsorption phenomena, influencing the distribution of the solute in the bulk solution and the formation of the external boundary film. Fig. 3 shows the adsorption capacity of the reactive dyes (Reactive Red 31 and Reactive Red 2) at different agitation speed (100, 120 and $140 \mathrm{rpm})$. From the figure it is clear that the dye uptake increases from $100 \mathrm{rpm}$ to $120 \mathrm{rpm}$ and shows a slight decrease at 140 $\mathrm{rpm}$. It is confirmed that $120 \mathrm{rpm}$ is the optimum agitation for the adsorption process. At higher agitation speed there may be a process of desorption at the equilibrium time. Thus, the difference in agitation speed

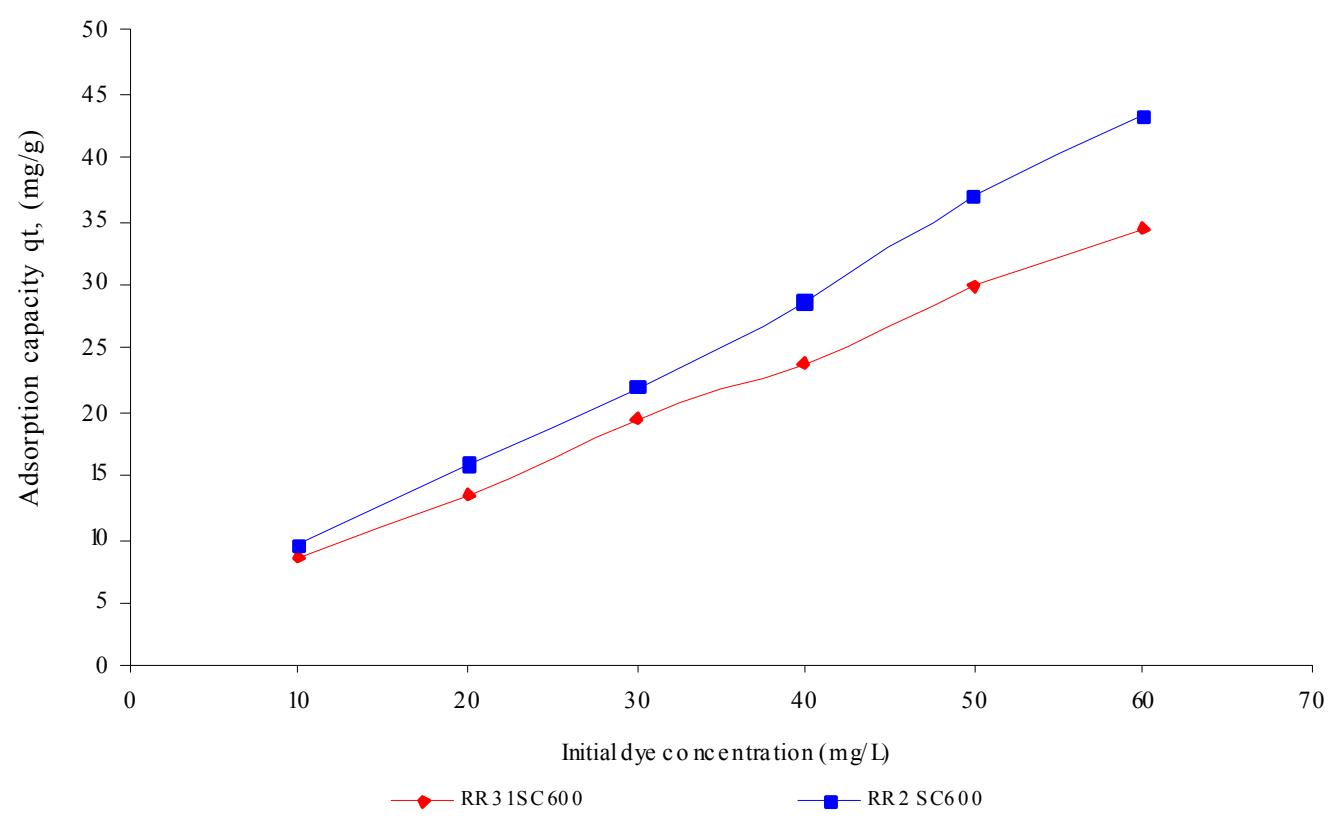

Fig. 1: Effect of initial dye concentration at $120 \mathrm{rpm}, 30{ }^{\circ} \mathrm{C}$ and $\mathrm{pH}=7.0$ 


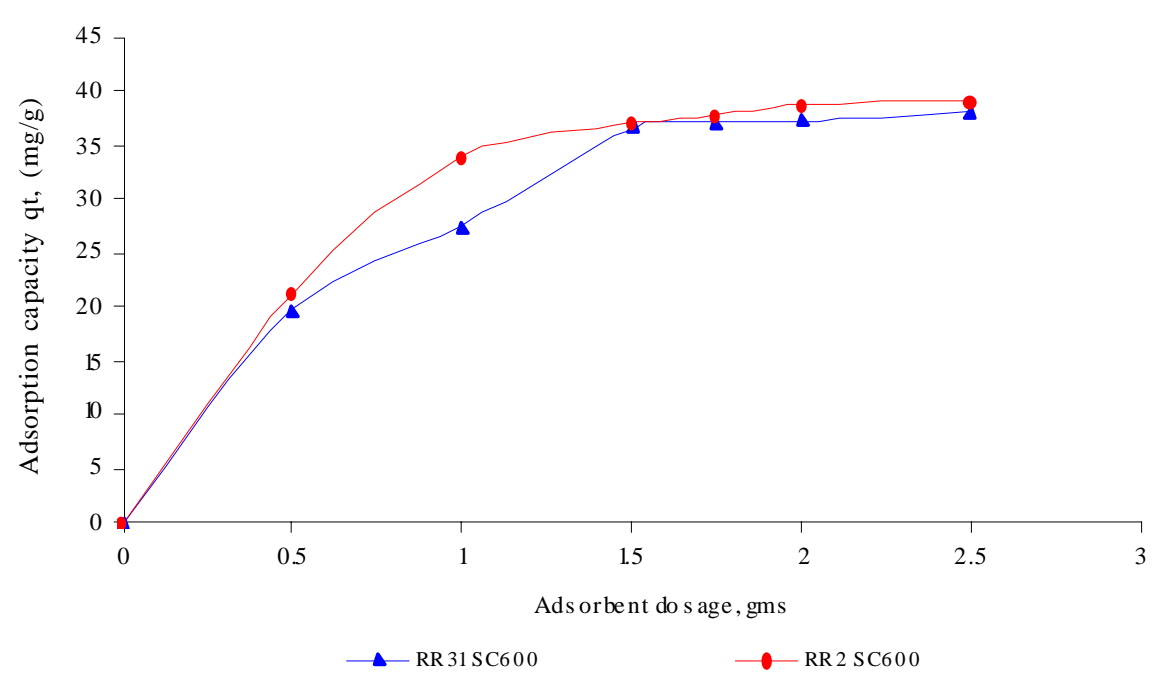

Fig. 2: Effect of adsorbent dosage at $40 \mathrm{mg} / \mathrm{L}$ of adsorbate concentration at $120 \mathrm{rpm}, 30{ }^{\circ} \mathrm{C}$ and $\mathrm{pH}=7.0$

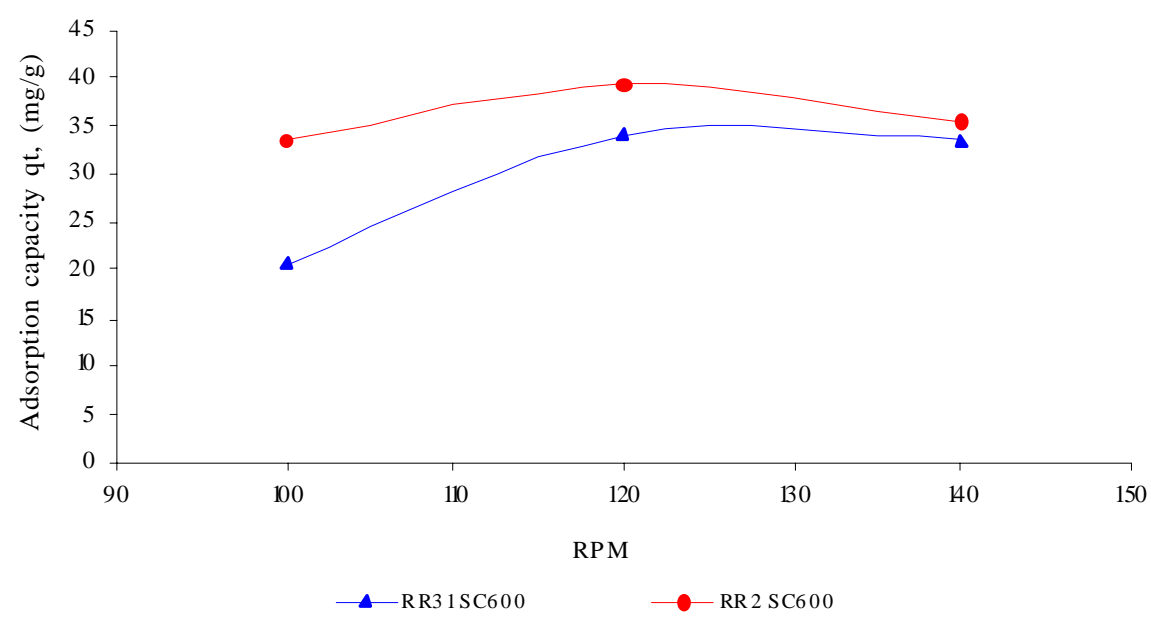

Fig. 3: Effect of varying RPM at $40 \mathrm{mg} / \mathrm{L}$ of adsorbate concentration at $30{ }^{\circ} \mathrm{C}$ and $\mathrm{pH}=7.0$

causes change in kinetics of the adsorption as well as the equilibrium adsorption capacity. Monoazo dye RR 2 has a greater adsorption capacity than diazo RR 31 dye. The increase in dye uptake at the optimum speed $(120 \mathrm{rpm})$ reduces the film boundary layer surrounding particles, thus increasing the external film transfer coefficient and hence the percentage dye removal.

\section{Effect of pH of adsorption kinetics}

The variation in adsorption of two reactive dyes by SC600 over a broad range of $\mathrm{pH}(2-11)$ at an initial dye concentration of $40 \mathrm{mg} / \mathrm{L}$, carbon dosage $1 \mathrm{~g}$, at temperature $30^{\circ} \mathrm{C}$ and agitation speed of $120 \mathrm{rpm}$ is shown in Fig. 4. The amount adsorbed decreased from 39.3 to $30.2 \mathrm{mg} / \mathrm{g}$ for RR 31 and from 36.4 to $30.8 \mathrm{mg} / \mathrm{g}$ for RR 2 respectively, as $\mathrm{pH}$ increased from 2 to 11 . Similar results were shown by Santhy and Selvapathy (2006) in the removal of reactive red dye. Adsorption of both the reactive dyes was found to be $\mathrm{pH}$ dependent. A useful index that indicates whether the surface is likely to become negatively or positively charged as a function of the $\mathrm{pH}$ is the $\mathrm{pH}$ value at which the net electric charge of the surface is zero. This value is called the zero point charge $\left(\mathrm{pH}_{\mathrm{zpc}}\right)$ or the $\mathrm{pH}$ value of isoelectric point of zeta potential $\left(\mathrm{Z}_{\mathrm{IEP}}\right)$. 
From Fig. 5, $\mathrm{pH}_{z \mathrm{pc}}$ of SC600 for RR 31 and RR 2 were 9.0 and 7.0 respectively. $\mathrm{A} \mathrm{pH}$ value lower than the $\mathrm{pH}_{\mathrm{zpc}}$ indicates that the superficial charge is positive and therefore the adsorption of the anions are favoured. For $\mathrm{pH}$ value higher than the $\mathrm{pH}_{\mathrm{zpc}}$ indicates that the superficial charge is negative and the adsorption of cations are favoured. Similar results were reported by Al-Degs et al. (2000) in the adsorption of commercial activated carbon F-400 on three reactive dyes. The $\mathrm{pHzpc}$ value for F-400 was found to be 7.2 and the $\mathrm{pH}$ values measured at equilibrium for the three reactive dyes studied were 5.5, 5.0 and 5.0, respectively, for the yellow, black and red reactive dyes. Low $\mathrm{pH}$ values strongly indicate that the activated carbon F-400 has a positive charge in the external layer (at equilibrium $\mathrm{pH}<$ $\mathrm{pH}_{\mathrm{zpc}}$ ) during the adsorption process. This positive charge attracts the negative portions of the reactive dyes. This behavior was also observed by Netpradit et al.
(2004) who obtained a $\mathrm{pH}_{\mathrm{zpc}}$ of around 8.7, favoring the uptake of the negative charge of the reactive dyes.

\section{Equilibrium adsorption Isotherms}

The analysis of the isotherm data by fitting them to different isotherm models is an important step to find the suitable model that can be used for design of adsorption systems. Two adsorption isotherm models Langmuir and Freundlich were used in this work. The applicability of the isotherm models to the adsorption study was compared by judging the correlation coefficients, $\mathrm{r}^{2}$ values.

\section{Langmuir isotherm}

The Langmuir isotherm assumes monolayer adsorption onto a surface containing a finite number of adsorption sites of uniform strategies of adsorption with

$$
C_{e} / q_{e}=1 / Q_{0} b+C_{e} / Q_{0}
$$

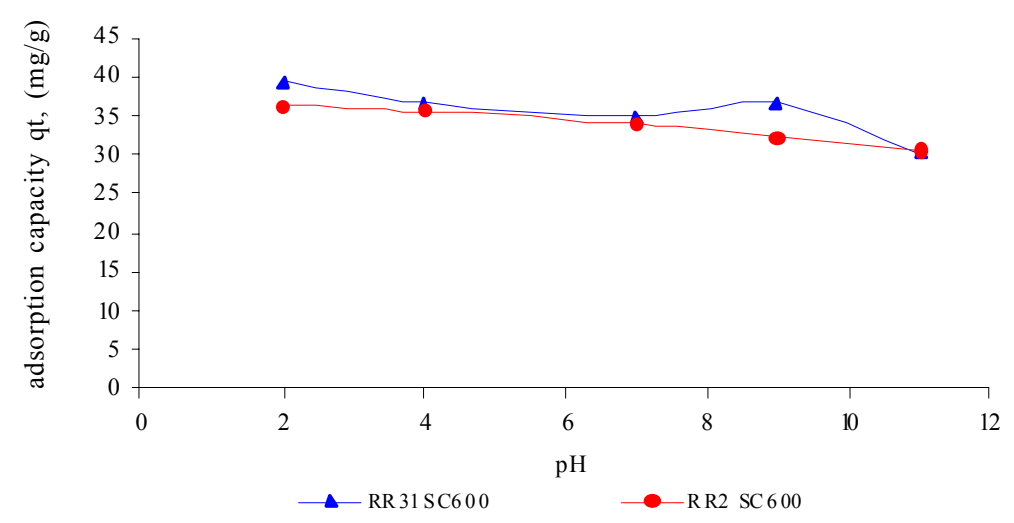

Fig. 4: Effect of $\mathrm{pH}$ at $40 \mathrm{mg} / \mathrm{L}$ of adsorbate concentration at $120 \mathrm{rpm} 30{ }^{\circ} \mathrm{C}$

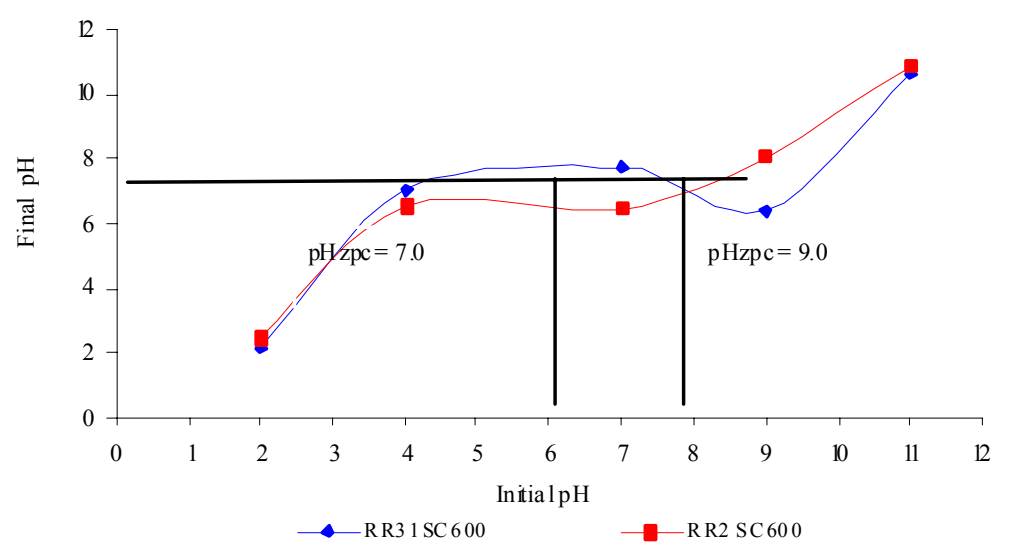

Fig. 5: Experimental determination of $\mathrm{pH}_{\mathrm{zpc}}$ of reactive dye on $\mathrm{SC} 600$ 
no transmigration of adsorbate in the plane of surface. The Langmuir equation can be expressed in mathematical form as in Eq. 2. Where, $C_{e}$ is the equilibrium concentration $(\mathrm{mg} / \mathrm{L}), q_{e}$ is the amount adsorbed at equilibrium (mg/g), $Q_{o}$ is the adsorption capacity (mg/ g) and $b$ is the energy of adsorption (Langmuir constant, $1 / \mathrm{mg}$ ). The maximum adsorption capacity and Langmuir constant were calculated from the slope and intercept of the linear plots $C_{e} / q_{e}$ versus $C_{e}$ to determine the value of $Q_{o}(\mathrm{mg} / \mathrm{g})$ and $b(\mathrm{~L} / \mathrm{mg})$, which gives a straight line of slope $1 / Q_{o}$, corresponding to complete monolayer coverage (mg/g) and the intercept is $1 / Q_{o} b$. The results are presented in Table 3 . The maximum adsorption capacity $Q_{0}$ was found to increase with the temperature, thereby enhancing the mobility of the dye ions. This led to a higher chance of the reactive dyes being adsorbed onto the adsorbent and an increase in its adsorption capacity which resulted in the enlargement of pore size or activation of the adsorbent surface. The isotherm showed no linear variation for the Langmuir constant $b$ and hence the kinetic energy of the dye was independent. The observed linear relationship is statistically significant (at the $95 \%$ confidence level) as evidenced by the $\mathrm{R}^{2}$ values (which are close to unity). This indicates the applicability of the isotherm (Langmuir isotherm) and the surface. The essential characteristics and the feasibility of the Langmuir isotherm is expressed in terms of a dimensionless constant separation factor or equilibrium parameter $\mathrm{R}_{\mathrm{L}}$, as in Eq. 3 :

$R_{L}=\frac{1}{1+b C}$

Where $C$ is the highest initial concentration of the adsorbate, $\mathrm{b}$ is the Langmuir constant $(\mathrm{mg} / \mathrm{L})$ and $R_{\mathrm{L}}$ value indicates the shape of the isotherm as follows: The range of $\mathrm{R}$ value is significant in defining the nature of adsorption (Table 3). $\mathrm{R}_{\mathrm{L}}$ values lie between 0 and 1 , indicating the adsorption systems are favorable for both the dyes (Reactive Red 31 and Reactive Red 2) using different SC600.

\section{Freundlich isotherm}

The Freundlich isotherm describes equilibrium on heterogeneous surfaces and hence does not assume monolayer capacity and used to describe the adsorption. It relates the adsorbed concentration as the power functions of solute concentration. One of the limitations of the
Freundlich model is that the amount of adsorbed solute increases indefinitely with the concentration of solute in the solution. This empirical equation takes the form as Eq. 4:

$$
q_{e}=K_{F} C_{e}^{1 / n}
$$

The logarithmic form of the equation becomes as in Eq. 5

$\log \left(q_{e}\right)=\log K_{F}+\frac{1}{n} \log \left(C_{e}\right)$

Where, $\mathrm{K}_{\mathrm{F}}$ and $\mathrm{n}$ are the Freundlich constants, characteristic of the system. $\mathrm{K}_{\mathrm{F}}$ and $\mathrm{n}$ is indicator of the adsorption capacity and adsorption intensity, respectively. The slope and the intercept of the linear Freundlich equation are equal to $1 / \mathrm{n}$ and $\ln \mathrm{K}_{\mathrm{F}}$ respectively. It has been shown that $n$ values between 1 and 10 represent good adsorption potential of the adsorbent. The values of the Freundlich constants at different temperatures are shown in Table 4.

The experimental data fit well with the isotherm since the values of correlation coefficients $\left(\mathrm{R}^{2}\right)$ are close to unity. The linear correlation between the Freundlich constants $\left(\mathrm{K}_{\mathrm{F}}\right.$ and $\left.\mathrm{n}\right)$ and the adsorption capacities were not observed. Hence the adsorption of the solute concentration is not evident. This shows the complex nature of the adsorption of reactive dyes onto the activated carbon adsorbents. The experimental data is well suited to the Langmuir isotherm than the Freundlich isotherm. Therefore the adsorptions of the reactive dyes under consideration are linear in Langmuir isotherm plot.

\section{Adsorption kinetics}

The prediction of batch sorption kinetics gives the most important information for designing batch sorption systems. The nature of sorption process will depend on the physical or chemical characteristics of the adsorbent system and also on the system conditions. In order to investigate the mechanism of sorption, characteristic constants of sorption were determined using two simplest kinetic models, a Pseudo-first order equation of Lagergren based on solid capacity and a Pseudo-second order equation based on solid phase sorption (Ho and McKay, 1999; Ho, 2001). A linear form of Pseudo first order model Eq. 6 is:

$\log \left(q_{e}-q\right)=\log \left(q_{e}\right)-\frac{k_{1, a d}}{2.303} t$ 
where, $q_{e}$ is the amount of adsorbed dye at equilibrium $(\mathrm{mg} / \mathrm{g})$, q the amount of dye adsorbed at time $\mathrm{t}(\mathrm{min})(\mathrm{mg} / \mathrm{g})$ and $\mathrm{k}_{1, \text { ad }}$ is the rate constant of first-order sorption $\left(\mathrm{min}^{-1}\right)$. A linear plot of $\log \left(\mathrm{q}_{\mathrm{e}}-\mathrm{q}\right)$ against time $(\mathrm{t})$ allows obtaining the rate constant. The rate constant for the pseudo first order model are calculated from the slopes and intercepts of the plots of Eq. 5. The values of $\mathrm{k}_{1 \text {, ad }}$ and $\mathrm{q}_{\mathrm{e}}$ are summarized in Table 5 for the two reactive red dyes on to the tannery sludge activated carbon. The $\mathrm{q}_{\mathrm{e}}$ values increased with increase in concentration for all the dye adsorption onto the different activated carbons. In case of the pseudo first order kinetic model, the calculated $\mathrm{q}_{\mathrm{e}}$ was not equal to the experimental $\mathrm{q}_{\mathrm{e}}$ suggesting the insufficiency of the model to fit the kinetic data for the initial concentrations examined. In most cases in the literature, the Pseudo first order model does not fit the kinetic data well over the entire contact time range (Vijayaraghavan and Yeoung-Sang, 2006). Thus, good linearity of the Lagergren plots is no guarantee that the interactions will follow first order kinetics. The reason for these differences in the $\mathrm{q}_{\mathrm{e}}$ values was due to a time lag, possibly as a result of a boundary layer or an external resistance controlling the beginning of the sorption process. The pseudo second order adsorption mechanism indicated that adsorption of Reactive Red dyes onto the SC600 are controlled by chemical processes. The similar

Table 3: Langmuir isotherm constants and correlation coefficients for adsorption of the dyes using tannery sludge developed activated carbon

\begin{tabular}{ccccccccc}
\hline Adsorbents & \multicolumn{4}{c}{ SC600 RR31 } & \multicolumn{5}{c}{ SC600 RR2 } \\
\cline { 2 - 9 } Temperature & $\mathrm{q}_{0}$ & $\mathrm{~B}$ & $\mathrm{r}^{2}$ & $\mathrm{RL}$ & $\mathrm{q} 0$ & $\mathrm{~b}$ & $\mathrm{r}^{2}$ & $\mathrm{RL}$ \\
\hline $20^{\circ} \mathrm{C}$ & 23.148 & 0.969 & 0.984 & 0.957 & 47.619 & 2.234 & 0.981 & 0.991 \\
$30^{\circ} \mathrm{C}$ & 25.575 & 1.412 & 0.993 & 0.973 & 52.356 & 10.053 & 0.962 & 0.998 \\
$40^{\circ} \mathrm{C}$ & 35.842 & 0.782 & 0.966 & 0.966 & 52.632 & 1.301 & 0.955 & 0.986 \\
$50^{\circ} \mathrm{C}$ & 39.370 & 3.175 & 0.991 & 0.992 & 55.866 & 4.068 & 0.956 & 0.996 \\
\hline
\end{tabular}

Table 4: Freundlich isotherm constants and correlation coefficients for adsorption of reactive dyes on tannery sludge developed activated carbon

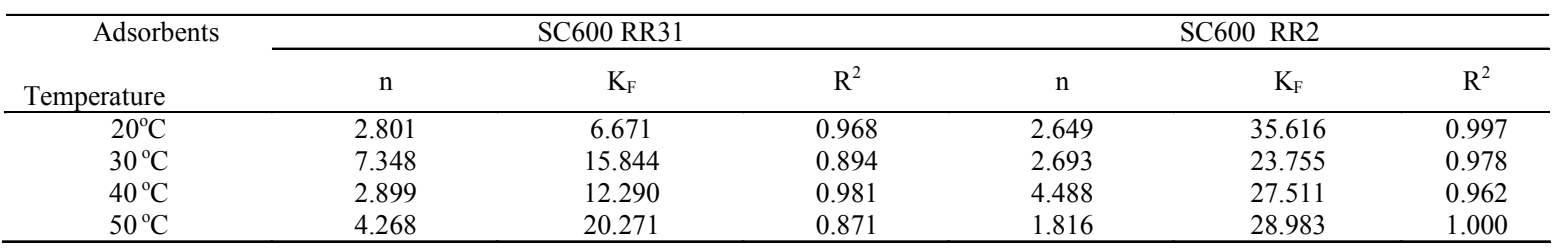

Table 5: Kinetic constants and correlation coefficients for adsorption of reactive dyes on tannery sludge developed activated carbon

\begin{tabular}{|c|c|c|c|c|c|c|c|c|c|c|c|c|}
\hline \multirow{3}{*}{$\begin{array}{l}\text { Adsorbents } \\
\text { Conc.mg/L }\end{array}$} & \multicolumn{6}{|c|}{ First order rate constamts } & \multicolumn{6}{|c|}{ Second order rate constants } \\
\hline & \multicolumn{3}{|c|}{ SC600 RR31 } & \multicolumn{3}{|c|}{ SC600 RR2 } & \multicolumn{3}{|c|}{ SC600 RR31 } & \multicolumn{3}{|c|}{ SC600 RR2 } \\
\hline & $\mathrm{K}_{1, \mathrm{ad}}$ & $\mathrm{q}_{\mathrm{e}}$ & $\mathrm{R}^{2}$ & $\mathrm{~K}_{1, \mathrm{ad}}$ & $\mathrm{q}_{\mathrm{e}}$ & $\mathrm{R}^{2}$ & $\mathrm{~K}_{2, \mathrm{ad}}$ & $\mathrm{q}_{\mathrm{e}}$ & $\mathrm{R}^{2}$ & $\mathrm{~K}_{2, \mathrm{ad}}$ & $\mathrm{q}_{\mathrm{e}}$ & $\mathrm{R}^{2}$ \\
\hline 10 & 0.031 & 2.619 & 0.989 & 0.007 & 1.573 & 0.978 & 0.010 & 8.873 & 0.993 & 0.011 & 9.111 & 1.000 \\
\hline 20 & 0.025 & 2.960 & 0.977 & 0.009 & 2.452 & 0.940 & 0.002 & 17.361 & 0.963 & 0.003 & 19.492 & 0.999 \\
\hline 50 & 0.013 & 4.581 & 0.999 & 0.004 & 3.773 & 0.966 & 0.001 & 36.364 & 0.909 & 0.001 & 49.251 & 0.995 \\
\hline 60 & 0.009 & 4.633 & 0.990 & 0.004 & 4.433 & 0.980 & 0.001 & 39.370 & 0.904 & 0.000 & 59.606 & 0.992 \\
\hline
\end{tabular}


phenomenon has also been observed in the adsorption of RR 120 (Yakup and Gulay, 2007; Annadurai et al., 2008).

\section{CONCLUSION}

These experimental studies have indicated that the preliminary tannery sludge developed activated carbon has the potential to act as an adsorbent for the removal of the two reactive dyes (RR 31 and RR 2) from aqueous solutions. The effects of initial dye concentration, adsorbent dosage, agitation speed, temperature and $\mathrm{pH}$ on the reactive dye removal were determined with the experimental data. The adsorption data correlated well with Langmuir model compared to the Freundlich isotherm model. The langmuir plot of RR 2 showed higher adsorbent capacity than RR 31 . The adsorption process also best suited with the pseudo second order kinetics with higher correlation coefficients.

\section{ACKNOWLEDGEMENTS}

Authors are thankful to the Department of Science and Technology (DST), Government of India, for the financial support. The project was performed with reference no. SR/WOS -A/ET-28/2007 and sanctioned for 3 years with a financial assisstance of Rs. $12,12,000$.

\section{REFERENCES}

Al - Degs, Y.; Khraisheh, M. A. M.; Allen, S. J.; Ahmad, M. N., (2000). Effect of carbon surface chemistry on the removal of reactive dyes from textile effluent. Water Res., 34 (3), 927-935(9 pages).

Annadurai Gurusamy.; Lai Yi Ling.; Jiunn - Fwu Lee., (2008). Adsorption of reactive dye from an aqueous solution by chitosan: isotherm, kinetic and thermodynamic analysis. J. Hazard. Mater., 152 (1), 337 -346 (10 pages).

Atafar, Z.; Mesdaghinia, A.; Nouri, J.; Homaee, M.; Yunesian, M., (2010). Effect of fertilizer application on soil heavy metal concentration. Environ. Monitor. Assess., 160 (1-4), 83-89 ( 7 pages).

Ciardelli, G.; Corsi, L.; Marucci, M., (2000). Membrane separation for wastewater reuse in the textile industry. Resour. Conserv. Recycl., 31(2), 189 - 197 (9 pages).

Chien, M. K.; Shih, L. H., (2007). An empirical study of the implementation of green supply chain management practices in the electrical and electronic industry and their relation to organizational performances. Int. J. Environ. Sci. Tech., 4 (3), 383-394 (12 pages).

Crini, G., (2006). Non-conventional low-cost adsorbents for dye removal: a review. Bioresour. Technol., 97 (9), 1061 1085 (25 pages).

Ferrero, F. (2000). Oxidative degradation of dyes and surfactant in the Fenton and photo - Fenton treatment of dyehouse effluents. J. Soc. Dyers Colour, 116 (5-6), 148 153 (6 pages).
Forgacs, E.; Cserhati, T.; Oros, G., (2004). Removal of synthetic dyes from wastewaters: A review. Environ. Int., 30 (7), 953 - 971 (19 pages).

Fung, P C.; Sin, K. M.; Tsui, S.M., (2000). Decolorization and degradation kinetics of reactive dye wastewater by UV/ultrasonic/peroxide system. J. Soc. Dyers Colour., 116 (5-6), 170 - 173 (4 pages)

Garg, V. K.; Gupta, R.; Yadavkumar, R., (2003). Dye removal from aqueous solution by adsorption on treated saw dust. Bioresour. Tech., 89 (2), 121-124 (4 pages).

Gharbani, P.; Tabatabaii, S. M.; Mehrizad, A., (2008). Removal of Congo red from textile wastewater by ozonation. Int. J. Environ. Sci. Tech., 5 (4), 495-500 (6 pages).

Hassani, A. H.; Mirzayee, R.; Nasseri, S.; Borghei, M.; Gholami, M.; Torabifar, B., (2008). Nanofiltration process on dye removal from simulated textile wastewater. Int. J. Environ. Sci. Tech., 5 (3), 401-408 (6 pages).

Ho, Y. S.; McKay, G., (1999). Pseudo-second order model for sorption processes. Proc. Biochem., 34 (5), 451 - 465 (15 pages).

Ho, Y. S., (2001). Sorption studies of acid dye by mixed sorbents. Adsorption, 7 (2), $139-147$ (9 pages).

Hsu, Y.; Chen, J.; Yang, H.; Chen, J., (2001). Decolorization of dyes using ozone in gas - induced a reactor. AIChE J. 47 (1), 169 - 176 (8 pages).

Martin, M. J.; Artola, A.; Dolors Balaguer, M.; Rigola, M., (2003). Activated carbons developed from surplus sewage sludge for the removal of dyes from dilute aqueous solutions. Chem. Eng. J., 94 (3), 231 - 239 (9 pages).

Naim, M. N.; El Abd, Y. M., (2002). Removal and recovery of dyestuffs from dyeing wastewaters. Sep. Purif. Methods., 31 (1), 171 - 228 (58 pages).

Nandi, B. K.; Goswami, A.; Purkait, M. K., (2009). Adsorption characteristics of brilliant green dye on kaolin. J. Hazard. Mater., 161 (1), 387 - 395 (9 pages).

Netpradit, S.; Thiravetyan, P.; Towprayoon, S., (2003). Application of waste metal hydroxide sludge for adsorption of azo reactive dyes, Water Res., 37 (4), $763-772$ (10 pages).

Netpradit, S.; Thiravetyan, P.; Towprayoon, S., (2004). Adsorption of three azo reactive dyes by metal hydroxide sludge: effect of temperature, $\mathrm{pH}$ and electrolytes. J. Colloid Interf. Sci., 270 (2), 255 - 261 (7 pages).

Orfaco, J. J. M.; Silva, A. I. M.; Pereira, J. C. V.; Barata, S. A.; Fonseca, I. M.; Faria, P. C. C.; Pereira, M. F. R., (2006). Adsorption of a reactive dye on chemically modified activated carbons - Influence of $\mathrm{pH}$. J. Colloid. Interf. Sci., 296 (2), 480 - 489 (10 pages).

Robinson, T.; McMullan, G.; Marchant, R.; Nigam, P., (2001). Remediation of dyes in textile effluent: A critical review on current treatment technologies with a proposed alternative. Bioresour. Tech., 77 (3), 247- 255 (9 pages).

Samarghandi, M. R.; Nouri, J.; Mesdaghinia, A. R.; Mahvi, A. H.; Nasseri, S.; Vaezi, F., (2007). Efficiency removal of phenol, lead and cadmium by means of UV/ TiO2/ $\mathrm{H}_{2} \mathrm{O}_{2}$ processes. Int. J. Environ. Sci. Tech., 4 (1), 19-25 ( 7 pages)

Santhy, K.; Selvapathy, P., (2006). Removal of reactive dyes from wastewater by adsorption on coir pith activated carbon. Bioresour. Tech., 97 (11), 1329 - 1336 (8 pages). 


\section{A. Geethakarthi; B. R. Phanikumar}

Shukla, A.; Zhang, Y. H.; Dubey, P.; Margrave, J. L.; Shyam, S. S., (2002). The role of sawdust in the removal of unwanted materials from water. J. Hazard. Mater., 95 (12), 137 - 152 (16 pages).

Sun, Q.; Yang, L., (2003). The adsorption of basic dyes from aqueous solution on modified peat- resin particle. Water Res., 37 (7), 1535 -1544 (10 pages).

Uygur, A.; Kok, F., (1999). Decolorization treatments of azo dye wastewaters including dichlorotriazinyl reactive groups by using advanced oxidation method. J. Soc. Dyers Colour, 115 (11), 350 - 354 (5 pages).

Vijayaraghavan, K.; Yeoung, S. Y., (2007). Utilization of fermentation waste (Corynebacterium glutamicum) for biosorption of Reactive Black 5 from aqueous solution. J. Hazard Mater., 141 (1), 45-52 (8 pages).

Walker, G. M.; Weatherley, L. R., (1999). Biological activated carbon treatment of industrial wastewater in stirred tank reactors. Chem. Eng. J., 75 (3), 201 - 206 (6 pages).

Yakup Arýca, M.; Bayramoglu Gulay., (2007). Biosorption of Reactive Red-120 dye from aqueous solution by native and modified fungus biomass preparations of Lentinus sajorcaju. J. of Hazard. Mater., 149 (2), 499 - 507 (9 pages).

Zvinowanda, C. M.; Okonkwo, J. O.; Shabalala, P. N.; Agyei, N. M., (2009). A novel adsorbent for heavy metal remediation in aqueous environments. Int. J. Environ. Sci. Tech., 6 (3), 425 - 434 (10 pages).

\section{AUTHOR (S) BIOSKETCHES}

Geethakarthi, A., M.E., Research scholar, Environmental Engineering, School of Mechanical and Building Sciences, VIT University, Vellore, India. Email: geethakarthi@yahoo.com

Phanikumar, B. R., Ph.D., Senior Professor, School of Mechanical and Building Sciences, VIT University, Vellore, India Email: phanikumar_29@yahoo.com

How to cite this article: (Harvard style)

Geethakarthi, A.; Phanikumar, B. R., (2011). Adsorption of reactive dyes from aqueous solutions by tannery sludge developed activated carbon: Kinetic and equilibrium studies. Int. J. Environ. Sci. Tech., 8 (3), 561-570. 